Creative commons User License: CC BY-NC-ND

Abstracted by: EBSCOhost, Electronic Journals Service (EJS),

Google Scholar, Directory of Open Access Journals (DOAJ),

Journal Seek, Scientific Commons,

Food and Agricultural Organization (FAO), CABI and Scopus
Journal of Agricultural Extension

Vol. XX (X) XXXXXX, 20XX

ISSN(e): 24086851; ISSN(Print); 1119944X

http://journal.aesonnigeria.org

http://www.ajol.info/index.php/jae

Email: editorinchief@aesonnigeria.org

\title{
Linking Maize Farmers to Market: A Case Study of Private Extension service in Yewa North Local Government Area of Ogun State, Nigeria http://dx.doi.org/10.4314/jae.v20i2.9
}

\section{Ladele, Ademola Adekunte}

Department of Agricultural Extension and Rural Development, University of Ibadan, Ibadan, Nigeria.

E-mail: aaladele@yahoo.com

Phone: +2348038565629

\author{
Akinwale, Jonathan Akinsola \\ Department of Agricultural Extension and Communication Technology, \\ Federal University of Technology, Akure, Ondo State, Nigeria. \\ E-mail: jonakinwale@yahoo.com \\ Phone: +2347032031707
}

\section{Oyelami, Benjamin Olusegun}

Department of Agricultural Extension and Rural Development,

University of Ibadan, Ibadan, Nigeria.

E-mail: oyelamibo@gmail.com

Phone: +2347062387036

\begin{abstract}
This paper presents the activities of a private extension outfit along maize value chain in Ogun state, Nigeria. The study reveals that the outfit performs functions that are not limited to knowledge transfer but as well as building integration and interaction among the diverse actors. The study further identified crucial performance indicators to evaluate success and ensure sustainability of the actors. Challenges such as breach of trust and sharp practices were also identified as obstacles to this approach. Meanwhile, farmers were able to experience improved linkage to market as a result of the well coordinated maize value chain. These findings had therefore demonstrated how private extension services in Nigeria are responding proactively to the pressure of changing roles and additional responsibilities of extension by rendering services that are not fully covered in public extension services.
\end{abstract}

Keywords: Private extension, Out-growers, Maize farmers.

\section{Introduction}

The challenges of feeding the world and ensuring sustainable livelihoods for smallscale farmers remain greater today than ever before. Many rural development efforts in Africa have focused on how to improve poor farmers' yield, but better yield has not 
Creative commons User License: CC BY-NC-ND

Abstracted by: EBSCOhost, Electronic Journals Service (EJS),

Google Scholar, Directory of Open Access Journals (DOAJ),

Journal Seek, Scientific Commons,

Food and Agricultural Organization (FAO), CABI and Scopus
Journal of Agricultural Extension

Vol. XX (X) XXXXXX, 20XX

ISSN(e): 24086851; ISSN(Print); 1119944X

http://journal.aesonnigeria.org

http://www.ajol.info/index.php/jae

Email: editorinchief@aesonnigeria.org

always translated into greater incomes for farmers (IFAD, 2015). This is largely because efficient market systems and better coordinated commodity chains are rarely in place. Thus, the role of efficient markets and a better coordinated commodity value chains have become increasingly important to producers and processors who depend on crop production for income. Meanwhile, the past decade has shown that agricultural development under increasingly complex conditions locally, nationally and globally - cannot be done alone by any single key actor. Effective interaction is needed between farmers on the one hand and business, research and development organisations on the other hand (Woodhill and Van Vugt, 2008).

Also, due to relative decline in public agricultural expenditure in the country, the past decades have witnessed increased interest in the agricultural sector, with a number of initiatives launched by government. Building on the regional momentum of the New Partnership for Africa's Development (NEPAD) and the Comprehensive Africa Agriculture Development Programme (CAADP), the overall thrust of Nigerian policy decisions and measures is to increase food production and commercialization, and develop the agribusiness sector through partnership between public and private or private and private organisations. Factors affecting the implementation of these initiatives and other agricultural strategies include poor budgetary allocation to agricultural sector, high ratio of extension agent/farm family, low technical and professional competencies and lack of required resources or political will on the part of governments (Haruna and Abdullahi, 2013; Ladele, 2011). Much can be gained if project-focused collaboration is complemented with structured, well-facilitated partnership at the organisational level. These allow organisations to join hands in setting strategic directions and identifying complementarities at an early stage. Such platforms help build mutual trust and, if they function well, form a powerful alliance to promote the joint agenda.

As farmers become more market oriented, so extension workers need to be in a position to advise them not only on how to grow crops but also on how to market them. Knowledge of produce handling, storage and packaging are essential in his 
Creative commons User License: CC BY-NC-ND

Abstracted by: EBSCOhost, Electronic Journals Service (EJS),

Google Scholar, Directory of Open Access Journals (DOAJ),

Journal Seek, Scientific Commons,

Food and Agricultural Organization (FAO), CABI and Scopus
Journal of Agricultural Extension

Vol. XX (X) XXXXXX, 20XX

ISSN(e): 24086851; ISSN(Print); 1119944X

http://journal.aesonnigeria.org

http://www.ajol.info/index.php/jae

Email: editorinchief@aesonnigeria.org

farming business (FAO, 2013). The missing link therefore is that public agricultural extension providers have been found wanting in rendering support services to farmers across the whole stretch of commodity value chains. For instance, Ovwigho (2015) found that the performance of public agricultural extension agents in Delta state was only good in dissemination of proven varieties of maize but poor on all other components of maize marketing. Similarly, Abugu, et al. (2013) identified sourcing farm input and marketing as the critical extension needs of farmers in Telfairia production in Enugu state. These are by no means lesser post-harvest functions than production in the complex arena, wherein the smallholder should transform to market oriented agri-business.

Maize is the most widely-grown staple food crop in sub-Saharan Africa (SSA) occupying more than 33 million hectares each year (Macauley and Ramadjita, 2015). The crop covers nearly $17 \%$ of the estimated 200 million hectares of cultivated land in SSA, and it is produced in diverse production environments and consumed by people with varying food preferences and socio-economic backgrounds. More than 300 million people in SSA depend on maize as a source of food and livelihood. The top 20 countries, namely South Africa, Nigeria, Ethiopia, Tanzania, Malawi, Kenya, Zambia, Uganda, Ghana, Mozambique, Cameroon, Mali, Burkina Faso, Benin, DRC, Angola, Zimbabwe, Togo, and Cote d'Ivoire account for $96 \%$ of the total maize production in SSA (Macualay and Ramadjita, 2015).

Maize is the commonest grain produced in Ogun state, Nigeria. It is produced within two seasons, namely, early and late maize. Its major economic importance is hinged on human consumption, livestock feeds and industrial processes including breweries and confectionaries. Majority of maize farmers in Nigeria operate largely in local markets due to lack of connectivity to more lucrative markets at local, national or global levels. As a result, incentives remain weak, investments remain low, and so does the level of technology adoption and productivity, resulting into a low level equilibrium poverty trap (Tomero, 2011). For the small holders to be brought out of the cycle of poverty, the roles of accompanying institutions such as agricultural extension services cannot be overemphasized. Smallholders, due to their small 
Creative commons User License: CC BY-NC-ND

Abstracted by: EBSCOhost, Electronic Journals Service (EJS),

Google Scholar, Directory of Open Access Journals (DOAJ),

Journal Seek, Scientific Commons,

Food and Agricultural Organization (FAO), CABI and Scopus
Journal of Agricultural Extension

Vol. XX (X) XXXXXX, 20XX

ISSN(e): 24086851; ISSN(Print); 1119944X

http://journal.aesonnigeria.org

http://www.ajol.info/index.php/jae

Email: editorinchief@aesonnigeria.org

surpluses in production, are generally exposed to a higher degree of risk and transaction costs (Mendoza and Thelen, 2008).

It is against this background that any innovative institutions that link farmers to markets, while reducing transaction costs and minimising risks will help them to participate in markets. Such a framework in a system of innovation is an interactive learning process in which enterprises/agents in interactions with each other, supported by organisations and institutions play key roles in bringing new products, new processes and new forms of organisations into social and economic use (Francis, 2006). Also, actors and stakeholders within the innovation system are permitted to identify their distinctive roles and understand their relationship to others in the system. The net result is the potential for better articulation, identification of gaps and challenges, and greater agreement, at least in principle, on the future requirements for the system (Paterson, Adam and Mullin, 2003). It has to be understood that the linkage between the farmer and the market is not just purely the buying and selling transaction of the crop, but that the linkage is the conduit for the flow of information, capacity building, finance and inputs. These factors are the vital elements of the system that facilitate the cost-effective movement of the crop from farmer to market, to meet the needs of both parties.

It therefore becomes imperative to examine how private extension services in Nigeria are becoming proactive in not only serving as a conduit of information but as well as linking farmers to essential commodity markets. Such market linkage(s) is capable of stimulating the productive base of smallholders, allowing increased volume and quality of crop to be available to the buyer. An effective market linkage increases opportunities for value addition toward sustainable agricultural growth. The study therefore gives a critical look into the activities of Pricewell Agrext Consult Limited (a private extension outfit) in linking maize farmers in Ogun state to markets.

\section{Objectives of the study}

The main objective of the study was to examine the sustainability of the activities of private extension service in linking maize farmers in Ogun state to markets. The specific objectives of the study were to: 
Creative commons User License: CC BY-NC-ND

Abstracted by: EBSCOhost, Electronic Journals Service (EJS),

Google Scholar, Directory of Open Access Journals (DOAJ),

Journal Seek, Scientific Commons,

Food and Agricultural Organization (FAO), CABI and Scopus
Journal of Agricultural Extension

Vol. XX (X) XXXXXX, 20XX

ISSN(e): 24086851; ISSN(Print); 1119944X

http://journal.aesonnigeria.org

http://www.ajol.info/index.php/jae

Email: editorinchief@aesonnigeria.org

1. describe linkages established by the private extension outfit with the maize farmers;

2. ascertain the effect of the linkages on farmers' yield; and

3. identify constraints in linking maize farmers to market.

\section{Methodology}

Case study research design was used for the study. The data used for the study was based on a field survey of 8 (4 closed out growers and 4 open out growers) farmers conducted between March and September, 2013 in Yewa North local government area of Ogun state. Maize, the only crop contracted was grown on 61.6 hectares of land area by the out growers. The choice of a case study approach is justified for the research because according to Yin (2003), case studies represent the appropriate research strategy for "how" and "why" questions about contemporary real-life phenomenon for which the researcher cannot manipulate the relevant behaviors.

The study applied participant observation and documentation [such as, memorandum of understanding and the field reports of Pricewell Agrext Consult Limited (Pricewell) (the private extension outfit)] during the period of the out grower scheme. Data collected included linkages established by Pricewell, effect of the linkages on farmers' yield and constraints in linking farmers to markets. Data were analysed using ratio analysis and descriptive statistics (percentages).

Ratio Analysis: this is the application of ratios in comparing similar variables. The variable in this study is the yield [that is, output $(\mathrm{kg})$ per unit area (ha)]. The yield from the demonstration plot was compared with farmers' yield from the two out growers. The degree of variation formed a measure of yield performance for the farmers. 
Creative commons User License: CC BY-NC-ND

Abstracted by: EBSCOhost, Electronic Journals Service (EJS),

Google Scholar, Directory of Open Access Journals (DOAJ),

Journal Seek, Scientific Commons,

Food and Agricultural Organization (FAO), CABI and Scopus
Journal of Agricultural Extension

Vol. XX (X) XXXXXX, 20XX

ISSN(e): 24086851; ISSN(Print); 1119944X

http://journal.aesonnigeria.org

http://www.ajol.info/index.php/jae

Email: editorinchief@aesonnigeria.org

\section{Results and Discussion}

\section{Framework for linking farmers to markets}

Pricewell Agrext Consult Limited adopted Commodity Alliance Model (CAM) as a platform for linking farmers to markets and integrating them in terms of fair price determination, information flow and issues resolution. According to Ladele and Ayoola (2011) key elements of the model include: backward integration programme; the purpose of partnering (this involves securing raw materials supply to indentified users and supplying the commodity at price remunerative to farmers and in the long run making agricultural inputs accessible and affordable to end users); key stakeholders and charter of partnership (this is based on a memorandum of understanding that assigns roles and responsibilities to partners).

Pricewell brokered a partnership arrangement with Golden Lad Nigeria Limited (an agro processor) in 2013 to enhance supply of maize to meet the company's raw material needs. Maize is processed by the company into semi-finished product which is later marketed to Nigeria Distilleries. The escalation in terrorists' activities (especially the scourge of boko haram insurgency) in the north east Nigeria at this period made the company to seek for alternative sources for her maize market. It was this situation that made Golden Lad to approach Pricewell and maize out grower scheme was initiated in Yewa North Local Government Area of Ogun State. The out grower scheme was operated between March and September, 2013. At this period, farmers were engaged on contract to produce SWAN 1 variety of maize exclusively for purchase by the company. The contracted farmers were closely monitored by Pricewell field agents during land preparation, planting, fertiliser application, weeding, harvesting and marketing stages.

A total of eight (8) farmers participated in the out grower scheme within the period of operation. The participants in the scheme were categorised into two, namely; closed and open out growers. The closed out growers involved formal agreement with four (4) farmers (otherwise known as 'Golden Lad farmers') who were to grow maize on the company's 40 hectares of land. The farmers were supported with inputs (maize seeds and fertilisers) as well as credit to perform farm operations from land 
Creative commons User License: CC BY-NC-ND

Abstracted by: EBSCOhost, Electronic Journals Service (EJS),

Google Scholar, Directory of Open Access Journals (DOAJ),

Journal Seek, Scientific Commons,

Food and Agricultural Organization (FAO), CABI and Scopus
Journal of Agricultural Extension

Vol. XX (X) XXXXXX, 20XX

ISSN(e): 24086851; ISSN(Print); 1119944X

http://journal.aesonnigeria.org

http://www.ajol.info/index.php/jae

Email: editorinchief@aesonnigeria.org

preparation to harvesting. This type of arrangement gave the company exclusive right to purchase the produce which the farmers at harvest would use to defray the loan accrued to them. On the other hand, farmers in the open out grower arrangement had the company's support only in areas of provision of maize seeds and guaranteed market at a mutually agreed predetermined price of N50.00/kilogram. The agreement with farmers in the open scheme was informal.

Within the few months of running the scheme, Pricewell field agents operated a demonstration plot for training and dissemination of recommended practices to the farmers. Similarly, officials of Pricewell trained the farmers on improved agronomic practices in maize cultivation, group dynamics and agricultural cooperatives. Furthermore, for strict compliance to recommended practices, Pricewell field agents maintained regular visits to the farmers in the two groups. Also, in order to minimise post-harvest losses, field agents ensured that maize cobs on farmers' field were below 13 percent moisture content before harvesting.

Subsequently, the harvested maize cobs were centrally aggregated, shelled, graded, and transported for onward delivery to the processor. The company honoured the agreement by purchasing all the aggregated maize produce from the farmers. Upon delivery of the shelled maize at the company's factory, payment was made at the predetermined price of $\$ 50.00 / \mathrm{kg}$ to individual farmers' bank account within 48 hours. The prompt payment by the processor and the transparent pricing formula that characterised the scheme was acknowledged by the farmers as great motivation to their participation in the scheme. Similarly, a premium of $A 5.00 / \mathrm{kg}$ was also paid above the predetermined price as an incentive for the participants by the company.

\section{Yield performance of the maize farmers}

\section{Maize yield from the demonstration plot}

Table 1 shows yield obtained from the demonstration plot established by the Pricewell extension agent. The yield of $2,075 \mathrm{~kg} / \mathrm{ha}$ from the demonstration plot was higher than the experimental/research yield for SWAM 1 variety that ranges between $1,500 \mathrm{~kg} / \mathrm{ha}-2,000 \mathrm{~kg} / \mathrm{ha}$ (Umar, Muhammad and Aliyu, 2013). This suggests that 
Creative commons User License: CC BY-NC-ND

Abstracted by: EBSCOhost, Electronic Journals Service (EJS),

Google Scholar, Directory of Open Access Journals (DOAJ),

Journal Seek, Scientific Commons,

Food and Agricultural Organization (FAO), CABI and Scopus
Journal of Agricultural Extension

Vol. XX (X) XXXXXX, 20XX

ISSN(e): 24086851; ISSN(Print); 1119944X

http://journal.aesonnigeria.org

http://www.ajol.info/index.php/jae

Email: editorinchief@aesonnigeria.org

with adequate agronomic practices, farmers can accomplish and even surpass yield potential in maize production. Considering the similarities between conditions in the demonstration plot and farmers' field, yield from the demonstration plot was then used as yield potential for the two groups of farmers.

\section{Table 1: Maize yield from the demonstration plot}

\begin{tabular}{cccc}
\hline Demo & $\begin{array}{l}\text { Area of land } \\
\text { (ha) }\end{array}$ & Output (kg) & Yield (kg/ha) \\
\hline 1 & 0.16 & 332 & 2,075 \\
\hline Source: Field survey, 2013 & &
\end{tabular}

\section{Yield performance of closed out growers}

Table 2 shows that farmers in the closed out grower arrangement achieved $872.9 \mathrm{~kg} / \mathrm{ha}$ yield from maize production. A further analysis of this result indicates $42.1 \%$ yield potential. The result is below $50 \%$ yield potential recorded for global maize production (Licker et al., 2010). This result suggests that farmers in the closed out grower were not able to apply various trainings received from the Pricewell field agents on good management practices like appropriate land preparation, timely planting, correct seed rate, spacing, weed control and optimum fertiliser application. This situation led to inefficient use of scarce resources provided by Golden Lad to the closed out growers.

Table 2: Yield of closed out growers

\begin{tabular}{ccccc}
\hline Farmers & $\begin{array}{l}\text { Area of land } \\
\text { (ha) }\end{array}$ & Output (kg) & Yield (kg/ha) & \% of Demo \\
\hline 1 & 8.0 & 8,261 & & \\
2 & 8.0 & 7,599 & & \\
3 & 16.0 & 12,251 & & \\
4 & 8.0 & 6,806 & & \\
TOTAL & 40.0 & 34,917 & & \\
\hline Yield & & & 872.9 & 42.1 \\
$\%$ of Demo & & & &
\end{tabular}

Source: Field survey, 2013 
Creative commons User License: CC BY-NC-ND

Abstracted by: EBSCOhost, Electronic Journals Service (EJS),

Google Scholar, Directory of Open Access Journals (DOAJ),

Journal Seek, Scientific Commons,

Food and Agricultural Organization (FAO), CABI and Scopus
Journal of Agricultural Extension

Vol. XX (X) XXXXXX, 20XX

ISSN(e): 24086851; ISSN(Print); 1119944X

http://journal.aesonnigeria.org

http://www.ajol.info/index.php/jae

Email: editorinchief@aesonnigeria.org

\section{Yield performance of open out growers}

Table 3 shows that farmers in the open out growers' scheme achieved $663.7 \mathrm{~kg} / \mathrm{ha}$ yield from maize production. A comparison of this outcome shows that the farmers were able to achieved $32.0 \%$ of potential yield. Although the yield performance of the two groups was far from matching that of the demonstration plot, the $42.1 \%$ of yield potential from the closed farmers can be said to be higher than $32.0 \%$ from the open system. The improved access to agricultural support services by the closed out growers' may be responsible for this marginal difference. This supports the finding of Ajah and Nmadu (2012), that adequate access to inputs determines maize farmer's productivity in Abuja, Nigeria.

Table 3: Yield of closed out growers

\begin{tabular}{lcclc}
\hline Farmers & $\begin{array}{l}\text { Area of land } \\
\text { (ha) }\end{array}$ & Output $\mathbf{( k g )}$ & $\begin{array}{l}\text { Yield } \\
\text { (kg/ha) }\end{array}$ & \% of Demo \\
\hline 1 & 8.0 & 4,464 & & \\
2 & 3.6 & 5,870 & & \\
3 & 8.0 & 2,206 & & \\
4 & 2.0 & 1,796 & & \\
TOTAL & 21.6 & 14,336 & & \\
\hline Yield & & & 663.7 & 32.0 \\
\% of Demo & & & & \\
\hline
\end{tabular}

Source: Field survey, 2013

\section{Constraints to effective market linkages among maize farmers}

The wide gap in potential yield and actual yield show that the farmers had not fully adopted the recommended practices disseminated to them. The fact is that farmers found new practices that are not in consonance with their current farming techniques awkward and did not want to give it a trial. For instance, during one of the training session, the farmers referred to the field agents as pen and paper farmers who lack prerequisite knowledge to offer on maize production. The non-compliance of the farmers with agronomic practices affected the quality and quantity of maize yield and subsequently affected financial returns to both parties.

There were also issues involving sharp practices as noticed from pocket of reports of side selling, inputs diversion, misappropriation of resources for specific farm operations. This type of situation in which farmers fail to live up to their side of the 
Creative commons User License: CC BY-NC-ND

Abstracted by: EBSCOhost, Electronic Journals Service (EJS),

Google Scholar, Directory of Open Access Journals (DOAJ),

Journal Seek, Scientific Commons,

Food and Agricultural Organization (FAO), CABI and Scopus
Journal of Agricultural Extension

Vol. XX (X) XXXXXX, 20XX

ISSN(e): 24086851; ISSN(Print); 1119944X

http://journal.aesonnigeria.org

http://www.ajol.info/index.php/jae

Email: editorinchief@aesonnigeria.org

agreement after enjoying a wide array of support services may weaken the scheme and also pose as a serious barrier to sustaining the commitment of the processor.

Furthermore, the transaction costs associated with interest on credits, provision of inputs and transportation of harvested produce may serve as hindrance for processors to contract with small-holders. The reason being that such costs increase the overhead and serve as disincentives for processors to engage with smallholder farmers in doing business as the returns on investment may not justify the costs of coordination.

\section{Conclusion and Recommendation}

Successful market linkages can be fostered between farmers and other stakeholders through innovative intervention by an intermediary such as private extension services. Meanwhile, the actual yield of the farmers was found to be below the yield potential which indicates lack of full adherence to agronomic practices by the farmers. Nevertheless, just as in many out grower schemes, the failure of farmers to honour contract agreements with some elements of sharp practices have proven to discouraging challenge. Thus, private extension outfit should make conscious effort to promote and encourage farm-level production wherein it brokers and coordinates all the activities from production to marketing. Similarly, for sustainability of future endeavours, the private extension outfit should work with agricultural development programme officials in selecting credible farmers with track record of trust and accountability to contract agreements so as to make the relationship more viable and attractive to the stakeholders.

\section{References}

Abugu, R. O., Chan, J. M., Nwobodo, C., Asadu, A. N. and lgbokwe, E. M. 2013. Agricultural extension needs of farmers in Telfairia production and marketing in Enugu state, Nigeria. Journal of Agricultural Extension, 17 (1), 49 - 60.

Ajah, J., and J. N. Nmadu 2012. Small-scale maize farmers access to farm inputs in Abuja, Nigeria. Kasetsart. Journal of Social Sciences, 33 (3) 499 - 505. 
Creative commons User License: CC BY-NC-ND

Abstracted by: EBSCOhost, Electronic Journals Service (EJS),

Google Scholar, Directory of Open Access Journals (DOAJ),

Journal Seek, Scientific Commons,

Food and Agricultural Organization (FAO), CABI and Scopus
Journal of Agricultural Extension

Vol. XX (X) XXXXXX, 20XX

ISSN(e): 24086851; ISSN(Print); 1119944X

http://journal.aesonnigeria.org

http://www.ajol.info/index.php/jae

Email: editorinchief@aesonnigeria.org

Food and Agriculture Organisation 2013. Marketing extension. August 3rd, 2016 from http://www.fao.org/ag/ags/agricultural-marketing-linkages/marketingextension/en.

Francis, J. 2006. National Innovation System Relevance for Development. Training of Trainers Workshop for ACP Experts on Agricultural Science, Technology and innovation (ASTI) system $2^{\text {nd }}-3^{\text {rd }}$ October, 2006. Food and Agriculture, 2013. Marketing extension. Retrieved on 31 $31^{\text {st }}$ March, 2016 from http://www.fao.org/ag/ags/agricultural-marketing linkages/marketingextension/en.

Haruna, S. K. and Abdullahi, Y. M. G. 2013. Training of Public Agents in Nigeria and the Implications for Governments Agricultural Transformation Agenda. Journal of Agricultural Extension, 17 (2), 98 - 104.

International Fund for Agricultural Development 2015. Cassava Factsheet Improving marketing strategies in Western and Central Africa. Retrieved on March 31st, 2016 from http://www.ifad.org

Ladele, A. A. 2011. Approaches to private agricultural extension service delivery in Africa: lessons from current development initiatives in Nigeria. A paper presented at the International Conference on Innovation in Extension and Advisory Services, Nairobi Kenya, November 15-18, 2011.

Ladele, A. A. and G. B. Ayoola, 2011. Commodity Alliance Model - An Option for Advancing Private and Commercial Extension Service Delivery. Journal of Agricultural Extension, 15 (2), 70 - 78.

Licker, R., M. Johnston, J. A. Foley, C. Barford, C. J. Kucharik, C. Monfreda, N. Ramankutty 2010. Mind the gap: how do climate and agricultural management explain the 'yield gap' of croplands around the world? Global Ecological Biogeography. $19(1), 769-782$.

Macauley, H. and T. Ramadjita 2015. Cereal crops: rice, maize, millet, sorghum and wheat. Abdou Diouf International, Dakar Senegal, October 21-23, 2015.

Mendoza, R. U. and N. Thelen 2008. Innovations to make markets more inclusive for the poor. Development policy review, 26 (4), 427-458.

Ovwigho, B. O. 2015. Role perception and performance of agricultural extension agents in maize marketing in Delta State, Nigeria. Journal of Biology, Agriculture and Healthcare, 5 (15), 7 - 13.

Paterson, A., R. Adam, and J. Mullin. 2003. The Relevance of the National System of Innovation Approach to Mainstreaming Science and Technology for Development in NEPAD and the AU. Pretoria, South Africa: NEPAD. 
Creative commons User License: CC BY-NC-ND

Abstracted by: EBSCOhost, Electronic Journals Service (EJS),

Google Scholar, Directory of Open Access Journals (DOAJ),

Journal Seek, Scientific Commons,

Food and Agricultural Organization (FAO), CABI and Scopus
Journal of Agricultural Extension

Vol. XX (X) XXXXXX, 20XX

ISSN(e): 24086851; ISSN(Print); 1119944X

http://journal.aesonnigeria.org

http://www.ajol.info/index.php/jae

Email: editorinchief@aesonnigeria.org

Tomero, M. 2011. A framework for linking small farmers to markets. A paper presented at the IFAD Conference on New Directions for Smallholder Agriculture, Rome, January 24-25, 2011.

Umar, U. A., M. B. Muhammad and A. S. Aliyu 2013. Maize production and yield improvement in Nigeria (1994 - 2013) Retrieved on 11 th October, 2016 from http://www.share4dev.info>fmard>documents.

Woodhill, J. and S. Van Vugt 2008. Facilitating multi-stakeholder and institutional change process: a societal learning process. Wageningen International Occasional Paper.

Yin R. K. 2003. Case Study Research Design and Methods. Applied Social Research Methods Series, 5 (3rd ed.) Sage, Thousand Oaks, CA 